\title{
"ONDE SERÁ A LOS ANGELES DO BRASIL?": CINEMA, IMPRENSA ILUSTRADA E VISÕES REGIONAIS DA MODERNIDADE NOS ANOS 1920
}

\author{
POR \\ Rielle NAVITSKI \\ University of Georgia
}

Em outubro de 1924, o "semanário cinematográfico" Selecta fez uma distinção geográfica curiosa ao comentar a grande quantidade de cartas recebidas de leitores desejosos de ser artistas de cinema. O jornalista observa: "Do interior dos Estados, principalmente, nos chegam elas [as cartas]. Parece que o filme, aí pelo sertão, vira a cabeça a muita gente, muito mais do que aqui no Rio" "Cinematográficas", 25 out. 1924). ${ }^{1}$ Sugerindo que os espectadores do interior manifestam uma mania de fazer parte do cinema (diferentemente dos cariocas, que presumidamente sabiam manter a distância adequada do espetáculo), esse comentário encerra algumas características-chave da relação entre o público leitor e as revistas cariocas de cinema dos anos 1920, que procuravam moldar as práticas de produção e consumo do cinema no Brasil. Publicações como Selecta, Cinearte e Para Todos... promoviam o desenvolvimento da produção e da exibição como um meio de combater o atraso do Brasil em geral e do "sertão" em particular. Em suas páginas, surgiam tensões entre os objetivos dos jornalistas de estabelecer um cinema nacional industrial (no modelo de Hollywood) e as ambições dos espectadores "provincianos" de fazer e aparecer em filmes disseminados ao nível local ou regional, ambições que são preservadas na cobertura da produção nacional. Esses desejos seriam realizados nos "ciclos regionais" dos anos 1920, surtos de produção cinematográfica fora do Rio e São Paulo que provocaram o jornalista Pedro Lima a perguntar em Selecta: "Onde Será a Los Angeles do Brasil?" (Lima, 19 julho 1924).

Neste ensaio, propomos que as revistas ilustradas brasileiras que se ocupavam da "sétima arte" constituíram o espaço principal onde se debatia e construía a cultura cinematográfica, um conjunto de práticas de sociabilidade e consumo estreitamente ligadas aos discursos de modernização nas primeiras décadas do século XX. Desde o surgimento das primeiras salas de cinema permanentes no Rio de Janeiro, em 1907,

As citações foram modificadas para conformar com o português contemporâneo. A revista se descreve como "semanário cinematográfico" em "Cinematográficas", Selecta, 3 de janeiro de 1925. 
as revistas ilustradas da capital tinham celebrado o novo meio como um estímulo para a atualização dos costumes. Tanto os leitores cariocas como os provincianos eram chamados a participar no espetáculo da vida moderna ao consumir-ou serem retratados por - imagens técnicas. Por contraste com estudos anteriores, que enfocam ou o papel do cinema na imprensa na virada do século $\mathrm{XX}^{2}$ ou as revistas de fã especializadas da década de $1920,{ }^{3}$ aqui ressaltamos as continuidades na relação cinema-imprensa nas duas épocas, chamando a atenção para a lógica intersubjetiva da revista ilustrada, construída como um modo de participação na modernidade incipiente do Brasil.

Surgidas em um panorama de publicações ilustradas que já se interessavam pelo cinema sem se especializar nele, as revistas de cinema cariocas dos anos 1920 eram indícios da institucionalização e americanização da cultura cinematográfica no Brasil na terceira década do século XX. Após a consolidação de circuitos integrados de importação, distribuição e exibição no Brasil, iniciada em 1911 pela Companhia Cinematográfica Brasileira de Francisco Serrador, a Primeira Guerra Mundial dificultou a produção e a exportação dos cinemas francês e italiano, favorecendo a expansão dos estúdios de Hollywood nos mercados da América Latina. O domínio do filme norte-americano, que chegou a oitenta por cento do mercado brasileiro no começo dos anos 1920 (Salles Gomes 299), acompanhava-se do surgimento da revista de fã. Esse gênero jornalístico aparece na imprensa carioca em 1921 com A Scena Muda, que contém entrevistas e fotos de artistas, artigos sobre as novidades de Hollywood e anúncios de bens de consumo, desde os automóveis até a maquiagem. Essas publicações constituem uma "mediação" privilegiada dos produtos culturais importados, um espaço onde surge uma cultura de massas no contexto das hegemonias culturais nacionais e internacionais (Martín Barbero). A negociação entre várias definições da modernidade cinematográfica que encontramos nas revistas de cinema cariocas ressalta a necessidade de estudos que reavaliem a oposição convencional entre o cinema brasileiro e o domínio de Hollywood, tendo em conta as tensões inerentes à construção de uma cultura nacional.

Nas revistas de fã, fortalecem-se as associações entre o cinema e a participação na modernidade através da adoção de hábitos, modas e gostos dos países mais industrializados, já evidentes na década anterior. As salas de cinema no centro do Rio de Janeiro, que tinha sido transformado pelas reformas urbanas do prefeito Francisco Pereira Passos (1903-1906), eram vistas como lugares essenciais para os novos rituais de circulação no espaço urbano (Melo Souza; Conde). Em 1914, a revista Fon-Fon publica desenhos de modas atuais ao lado de uma descrição de um passeio pelo Rio, a "cidade dos cinematógrafos", acompanhado pela observação minuciosa dos outros

2 Ver Melo Souza, Imagens do passado: São Paulo e Rio de Janeiro nos primórdios do cinema e Conde, Consuming Visions: Cinema, Writing, and Modernity in Rio de Janeiro.

3 Salles Gomes, "O cinema brasileiro visto de cinearte"; Xavier, "O sonho da indústria: a criação de imagem en Cinearte"; Autran, "Pedro Lima em Selecta"; Araújo, "O cinema silencioso pernambucano".

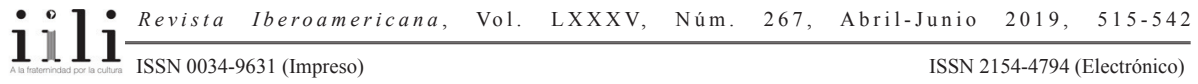


transeuntes (Fig. 1). Ainda que não haja uma relação direta entre imagem e texto, estão claras as associações entre a prática de frequentar a sala de cinema, um lugar privilegiado de visibilidade pública, e a de participar de novos modos de autoapresentação através dos bens de consumo (neste caso, o vestuário).

Na década seguinte, o cinema passará a ser concebido como veículo da modernização, além de ser um indício da modernidade. Selecta declara em 1929:

O cinema, hoje, é a escola, por excelência [...] principalmente nos lugares onde não é fácil a difusão das coisas do progresso atual, reflexos da evolução moderna dos costumes contemporâneos. Graças à introdução do cinema nas regiões afastadas dos centros civilizados, é que hoje nada nos falta, como conforto e expressão de modernidade e progresso, nas cidades ditas do interior. ("Cinematográficas”, 20 mar. 1929, 3)

Buscava-se um caminho ao progresso nacional por meio do cultivo de práticas "modernas" de exibição e na formação de um espectador culto, dentro e especialmente fora da capital.

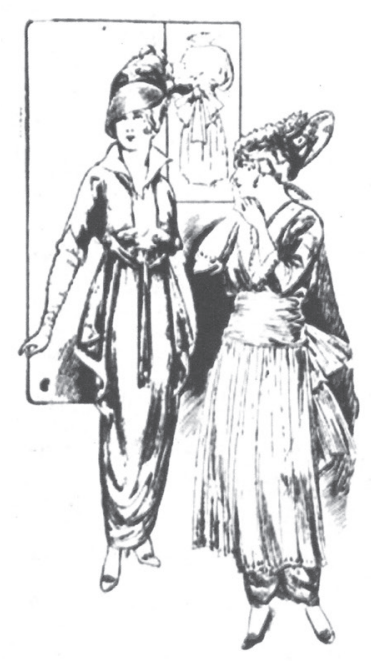

A MODA

0 Rio é a cidade dos cinematographos. E' divertido parar a gente a vêr a variedade $\mathrm{e} o$ pittoresco das physionomias que entram e sahem, alegres ou bisonhas umas, solemnes e graves outras, todas mais ou menos com esse ar papalvo e inexpressivo dos que se divertem.

As portas das casas que exhibem fitas, formigam eternamente de uma multidão ávida, inquieta, e a não ser o povo que prefere as distracções ao ar livre, como o corso, em Botafogo ou na Quinta, e o resumido numero de gedeões que costuma frequentar as festas de arte, o resto da população urbana se embiuca no primeiro cinema a proposito, assiste ao programma completo, sáe, perambula um pouco ainda; depois, toma o bonde do seu bairro e abala para os penates, com a consciencia tranquilla e mais alguns enredos a contar, na hora do chá, em familia...

Entretanto, confessando bem, o cinematographo é a unica couza intelligente, fixa, nesta immensa tapéra espiritual.

Ainda ha dias eu vi um film por Napierkowska, e aquella figura extranha, ondulante, encheu de belleza a minha semana...

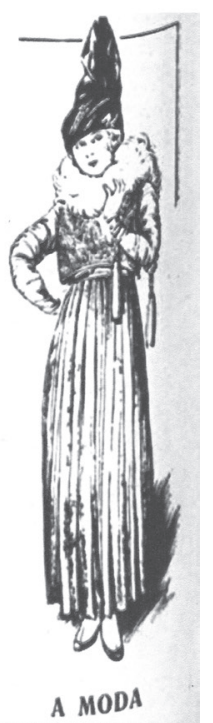

Fig. 1: "O Rio é a cidade dos cinematógrafos", Fon-Fon, 20 de junho de 1914. Hemeroteca Digital Brasileira.

Além de promover o consumo do cinema como meio de modernização, as revistas de cinema cariocas apresentam-se como provas de progresso cultural, enfatizando a atualidade de sua informação e do uso de tecnologias avançadas de impressão. Em

\begin{tabular}{l}
1110 \\
\hline ISSN 0034-9631 (Impreso)
\end{tabular} 
1927, Cinearte publica uma foto da atriz mineira Eva Nil em visita às instalações da revista, posando ao lado de uma enorme impressora de rotogravura com o jornalista Lima. Tanto a máquina como a presença de uma "estrela" nacional são apresentadas como motivos de orgulho para a publicação e para o cinema brasileiro nascente (Fig. 2). Naquele mesmo ano, Cinearte alega ser "bem conhecida nos meios cinematográficos americanos que se admiram de como no Brasil, que é apenas um mercado consumidor, se possa publicar um semanário cinematográfico como o nosso, com processos gráficos os mais modernos e adiantados, contendo matéria escolhida e sempre ao par das últimas novidades relativas ao Cinema" ("Crônica", 1 jun. 1927, 3). Na ausência de uma indústria cinematográfica nacional, Cinearte orgulha-se da sua emulação da revista de fã norte-americana, comparando-se à mais vendida delas ao denominar-se "o nosso Photoplay" ("O fulgor das nossas estrelas" 5). Ressaltando a semelhança

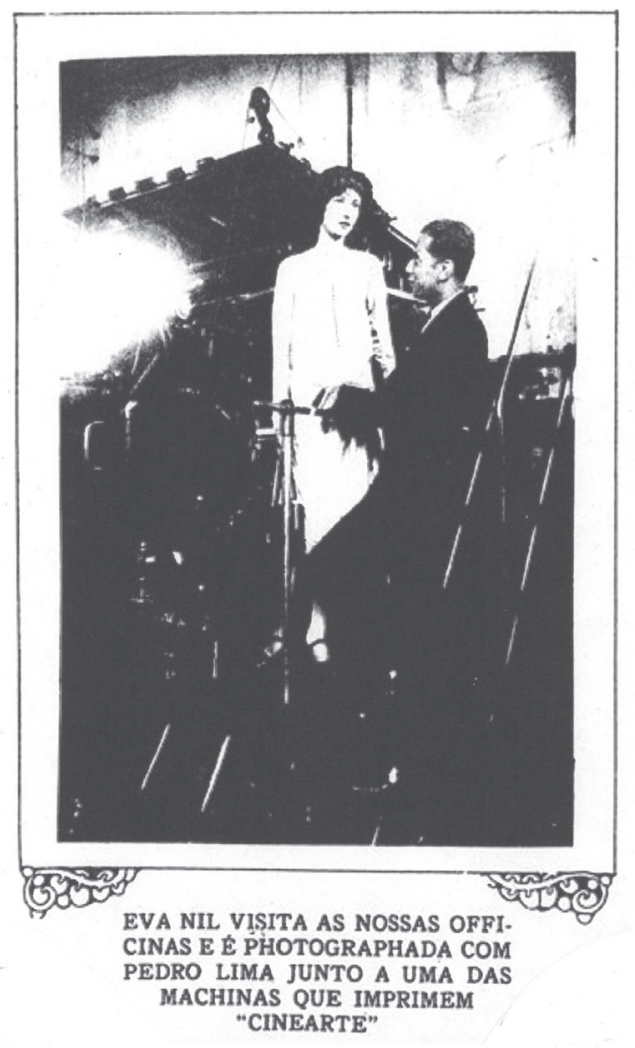

Fig. 2: Eva Nil em Cinearte, 12 de outubro de 1927. Hemeroteca Digital Brasileira.

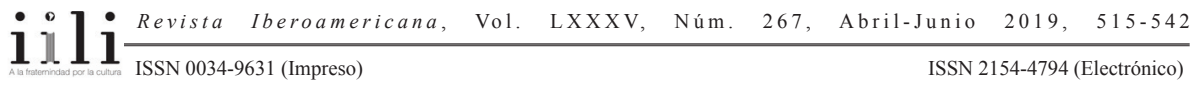


visual entre as duas revistas, o crítico Ismail Xavier afirma que esse "tipo de revista seria de grande utilidade na periferia" para o avanço dos interesses dos estúdios de Hollywood, já que "as agências americanas estariam prontas a lhe oferecer material (entrevistas, reportagens, artigos, fofocas) e lhe dar todo o incentivo intelectual e moral" (Xavier 168). Embora a participação de Cinearte nos processos de americanização seja inegável, Xavier desconsidera a estrutura interativa das revistas de fã norte-americanas, que assumirão dimensões mais radicais no caso brasileiro.

Marsha Orgeron observa que essas publicações solicitam a colaboração dos leitores para produzir o conteúdo das revistas (através da publicação de cartas e artigos deles) e até na produção de filmes, através dos "concursos fotogênicos" que prometiam converter a fã em estrela, "perhaps the ultimate and in some ways most radical act of sanctioned participation" (4). Ao mesmo tempo em que a revista enfatiza "the disparity between reader's ordinary lives and celebrities' extraordinary lives", ela oferece a possibilidade de eliminá-lo, "reproducing spectators not only as consumers but also as actors" (4, grifo no original).

A confusão deliberada entre o espectador e o ator encorajada pela revista de fã adquiriu matizes ainda mais complexos no Brasil na ausência de uma indústria cinematográfica. De acordo com Ana M. López, na América Latina na virada do século $\mathrm{XX}$, "cinema fed the national self-confidence that its own modernity was 'in progress' by enabling viewers to share and participate in modernity as developed elsewhere", porém, dado a escassa produção de filmes nacionais, "viewers had to assume the position of spectators and become voyeurs of, rather than participants in modernity" (53).

No entanto, nas imagens e discursos em torno do cinema na imprensa ilustrada brasileira, o espectador-isto é, o "voyeur" da modernidade importada-é constantemente visto como participante do espetáculo da vida moderna ao ser retratado pelas imagens técnicas. O jurista e político baiano Rui Barbosa, por exemplo, foi retratado pela revista Fon-Fon em 1910 após uma sessão de cinema, tal como as centenas de transeuntes e espectadores anônimos cujas fotografias apareceram nas páginas das revistas (Fig. 3).As fotografias de espectadores de cinema são um exemplo sobressalente da transformação da vida cotidiana em espetáculo, na interseção da fotografia, do cinema e da imprensa ilustrada, um fenômeno que se estende ao longo da década de 1920. Pode-se afirmar, inclusive, que a ausência de uma indústria nacional consolidada permite que a dinâmica participativa evidente na revista de fã se desenvolva de uma maneira mais radical. A proliferação de locais potenciais para a "Los Angeles do Brasil" em vários estados torna a transformação do fã em estrela mais alcançável. A produção e exibição de filmes no nível local parecia cumprir com a declaração feita por Walter Benjamin em 1936: "Cada pessoa, hoje em dia, pode reivindicar o direito de ser filmado" (183). Na cultura visual moderna, as fronteiras entre a vida cotidiana e o objeto estético tornamse altamente permeáveis.

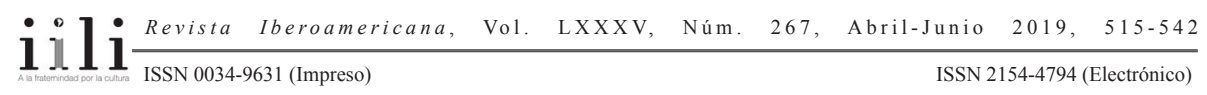




\section{O MOMENTO POLITICO}

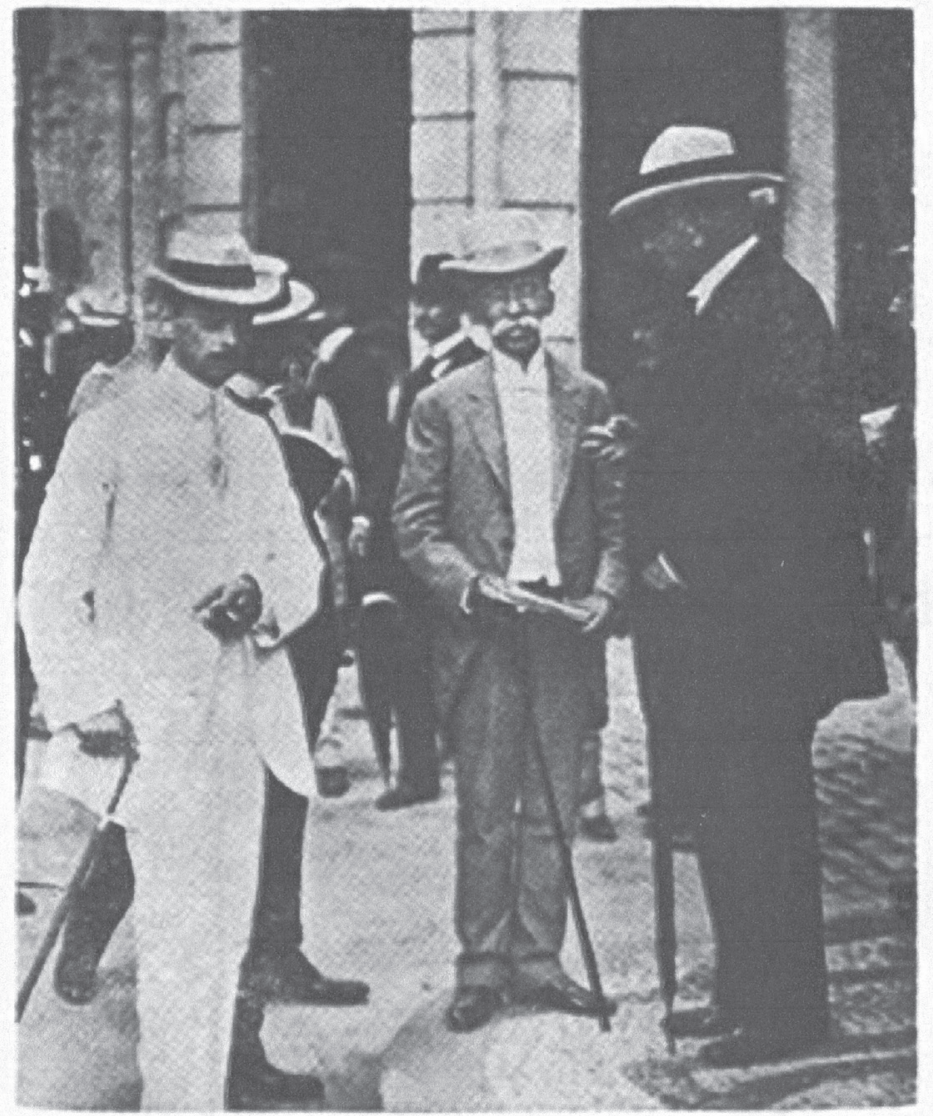

O Conselheiro Ruy Barbosa, na esquina da Avenida, depois: de assistir ao programma do Cinema Odeon.

(CLICHÉ DO FON-FON).

Fig. 3: Rui Barbosa, fã conhecido do cinema, em Fon-Fon, 5 de março de 1910. Hemeroteca Digital Brasileira

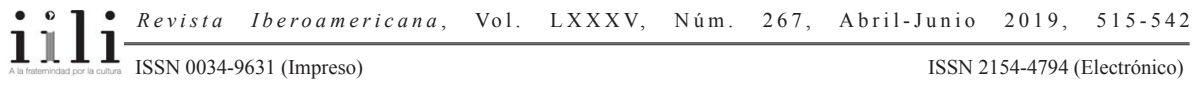


Nas páginas das revistas de cinema da década de 1920, as notícias sobre a produção regional se cruzam com ambições nacionais e cosmopolitas, sobretudo na célebre campanha em prol do cinema brasileiro iniciada por Lima e Adhemar Gonzaga em Selecta e Para Todos..., em 1924, e continuada pelos dois em Cinearte após sua fundação, em 1926. Adotando o lema "Todo filme brasileiro deve ser visto", Gonzaga e Lima desenvolvem uma série de estratégias interrelacionadas para promover, disseminar e moldar o cinema brasileiro. No entanto, o cinema nacional manifestou-se como tal somente nas páginas das revistas, que recolhiam e difundiam as atividades geograficamente dispersas dos produtores. Produtos da confluência de um mercado de exibição bem desenvolvido e da concentração da atividade jornalística no Sudeste do Brasil, as revistas de cinema tendiam a reforçar a centralidade cultural do Rio de Janeiro, núcleo de poder político, e em menor medida de São Paulo, que vivia um processo de rápida urbanização e industrialização.

Se ser filmado (ou filmar) era visto como indício poderoso de um cotidiano moderno, possuía um significado especial no contexto das dinâmicas de desenvolvimento econômico na época. Nos anos 1920, de acordo com Marly Rodrigues, a "expansão do capitalismo no Brasil", que se manifestava na "implantação de ferrovias, abertura de novas áreas de cafeicultura, concentração de mão de obra, crescimento da potência elétrica, do setor industrial e das cidades, havia selado a distinção entre o sul e as demais regiões do país" (22). Um modelo econômico baseado no cultivo de produtos agrícolas para exportação (açúcar e algodão no Nordeste, borracha na Amazônia, café nos estados de Minas Gerais, Rio de Janeiro e São Paulo) havia promovido um crescimento desnivelado. Nesse contexto, os governos estaduais e as elites do Nordeste e de Minas Gerais, entre outros locais, procuravam definir programas políticos, econômicos e estéticos que lhes permitiriam ter um papel ativo no devir do país. Enquanto os letrados debatiam a necessidade de modernização estética ou defendiam as suas tradições e privilégios históricos, ${ }^{4}$ os cineastas semiamadores de origem pequeno-burguesa (engenheiros, artesãos, donos de pequenos negócios) ambicionavam participar da modernidade através da produção de filmes (Cunha). Em alguns casos, eles contavam com apoio oficial, inclusive dos presidentes dos estados. ${ }^{5}$

Entre 1923 e 1930, quando a transição ao sonoro transformaria o quadro de produção cinematográfica no Brasil, o cinema brasileiro e os "ciclos regionais" em

4 Em Azevedo, Modernismo e regionalismo, Bomeny, Guardiães da razão: modernistas mineiros.

5 Em 1928, Antônio Carlos de Minas Gerais visitou os estúdios do cineasta Humberto Mauro durante a rodagem do seu filme Braza dormida, e assistiu a uma exibição do filme Entre as montanhas de Minas realizado por Manoel Talon, de acordo com Cinearte, 12 de dezembro de 1928, 4-5, 33 e 35 e Cinearte, 26 de setembro de 1928, 6. Um leitor de Selecta de Pernambuco afirma que o governador Sérgio Loreto assistiu ao filme Filho sem mãe de Tancredo Seabra em sessão especial, de acordo com "A opinião dos nossos leitores", Selecta, 24 de março de 1926.

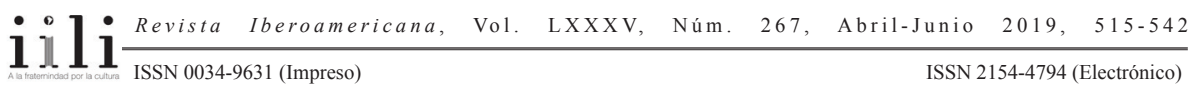


particular insistentemente constroem imagens da modernidade, em grande medida para públicos locais. Tanto documentários, como No país dos Amazonas (Silvino Santos, 1922) e Grandezas de Pernambuco (Chagas Ribeiro, 1924), como filmes de ficção retratam processos de produção locais e paisagens pitorescas, sejam rurais ou urbanas. ${ }^{6}$ Os filmes de enredo enfatizam as tecnologias modernas de transporte ${ }^{7}$ e a presença de modas e comportamentos modernos, exemplificada pela figura da "melindrosa" de cabelos e saias curtos. ${ }^{8} \mathrm{O}$ resumo do filme Quando elas querem (E.C. Kerrigan, São Paulo, 1925), por exemplo, ressalta o vestuário elegante da heroína Clarinda e o

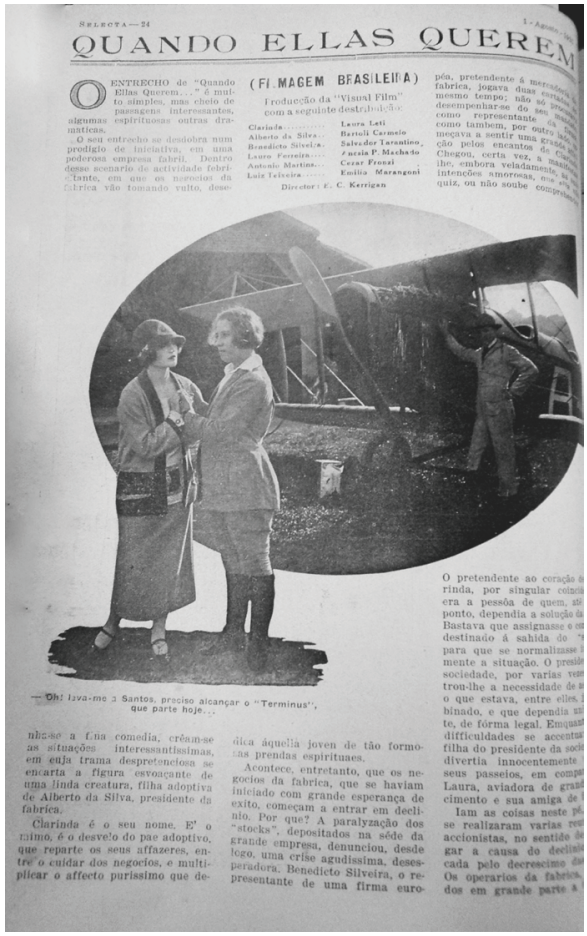

\footnotetext{
Fig. 4: Resumo do filme Quando elas querem.
Selecta, 1 de agosto de 1925 . Fundação Biblioteca

Fig. 4: Resumo do filme Quando elas querem.
Selecta, 1 de agosto de 1925 . Fundação Biblioteca Nacional, Brasil.
} conjunto masculino de sua amiga Laura, pilota do avião que aparece ao lado direito da montagem (Fig. 4). Tal como a viagem aérea que marca o clímax do enredo, o ênfase na mulher moderna - sedutora ou esportiva - testemunha o "progresso" do ambiente local.

Além de retratar aspectos de uma modernidade local incipiente, esses filmes constituíam um meio poderoso para se atingir a "inclusão do sujeito do olhar na periferia do capitalismo" (Cunha). O significado de apoderar-se do olhar da câmera era sentido sobretudo no nível local e regional, já que a circulação dos filmes em outras regiões era dificultada pela ausência de uma infraestrutura de distribuição de produções nacionais. Essa situação não satisfazia aos jornalistas cariocas, que tinham a ambição de estabelecer um cinema nacional, e agiam sem grande sucesso pela difusão ampla das produções. Dada essa situação, as revistas de cinema se empenham em disseminar (ou Nacional, Brasil.

6 Por exemplo, dedica-se um estendida sequência lírica a uma usina de açúcar no filme mineiro Braza dormida (Humberto Mauro, 1928).

7 Perseguições e desastres de automóvel têm um lugar preeminente no filme campineiro Mocidade louca (Thomaz de Tullio, 1927) e na produção belo-horizontina Entre as montanhas de Minas (Manoel Talon, 1928).

8 Destacam-se entre vários exemplos as protagonistas de Sangue mineiro (Humberto Mauro, 1930) e $A$ filha do advogado, produção recifense de Jota Soares, de 1926. 
inventar) um cinema brasileiro na página impressa, na forma de resumos dos enredos, retratos dos artistas e notícias sobre produções. Selecta declara em 1926: "Quanta vez, não temos lido em jornais e revistas de outros países da América, da França e até da Alemanha, notas soltas dizendo do incremento da filmagem no Brasil! E isto, não é que eles tenham visto nossos filmes, mas pelo que têm visto impresso nas nossas revistas" ("Desenvolvimento", 1 dez. 1926, grifos no original). O essencial era fazer visível a produção de filmes e a existência de "estrelas" brasileiras para um público nacional e internacional, como prova do progresso do país, ainda que isso ocorresse somente na página impressa.

Neste ensaio, rastreamos o desenvolvimento na imprensa ilustrada brasileira de um imaginário da cultura cinematográfica que se concebia como um modo de participação na vida moderna. Ao examinar um panorama amplo (em termos geográficos e cronológicos) de publicações periódicas, pretendemos cultivar um olhar comparativo que abrange os cenários privilegiados da modernização no Brasil e múltiplos lugares fora deles, por contraste com estudos focados no eixo Rio-São Paulo (Melo Souza; Conde) ou numa única cidade fora dele (Steyer; Silva Fonseca; Cunha). Diferentemente de análises anteriores que se concentram no impacto pretendido das revistas cariocas de cinema na produção nacional (Salles Gomes; Xavier; Araújo), nosso enfoque serão os imaginários de exibição e estrelato na imprensa ilustrada, que constituem espaços de espetacularidade nos quais o espectador se transforma em criador ou sujeito da cultura visual.

A PRESENÇA DO CINEMA NA IMPRENSA BRASILEIRA: DA REVISTA ILUSTRADA À REVISTA ESPECIALIZADA

Na virada do século XX, surgiram diversas inovações na imprensa brasileira, tanto na impressão como na distribuição das publicações, possibilitando a difusão rápida de imagens técnicas da atualidade a um amplo público. Em 1900, a Revista da Semana é lançada no Rio, tornando-se a primeira a aproveitar os processos de fotogravura para oferecer uma proliferação de imagens fotográficas. A revista Careta, surgida em 1908, tem a novidade de ser distribuída através dos correios, logrando penetrar velozmente nos outros estados (Eleutério 90). Após o surgimento de salas de cinema permanentes no Rio de Janeiro, o cinema torna-se não somente o sujeito de reportagens fotográficas e comentários, senão também um modelo para traduzir à página impressa o fluxo de diversas e efêmeras impressões características da vida cotidiana na metrópole (Süssekind). Considerada "a criação artística mais representativa da nossa época", nas palavras da revista modernista Klaxon ("Klaxon”, 15 maio 1922), o cinema facilita o surgimento de espaços físicos e práticas sociais que facilitam novas experiências de circulação pública e convivência coletiva.

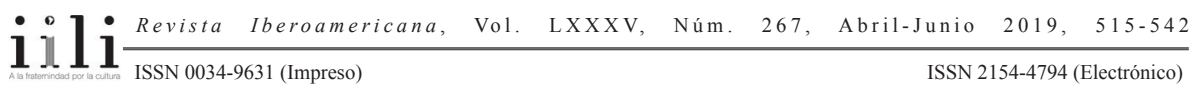


Nas páginas de Careta e Fon-Fon, o cinema torna-se o cenário privilegiado dos encontros furtivos da vida urbana. Os dramas cotidianos da rua são denominados "fitas", a metáfora organizadora de uma série de crônicas intitulada "Cinema-Carioca", publicadas na Careta pelo escritor e publicitário Bastos Tigre(Conde 73-77). Na mesma revista, aparece uma caricatura sugestiva que dirige o olhar do leitor aos espectadores de cinema, sugerindo que as "fitas" que se desenvolvem entre os espectadores - os flirts inocentes ou adúlteros na sala de espera ou na escuridão, o assédio pelos "bolinas", 9 as depredações dos ladrões - são tão fascinantes quanto os dramas na tela (Fig. 5). Se a sala de cinema é concebida como um espaço de encontros insólitos, um lugar para ver e ser visto (Fig. 6), a fachada se torna um elemento essencial do novo panorama

\section{$\mathbb{C I N E M A T O G R A P H O ~}$}

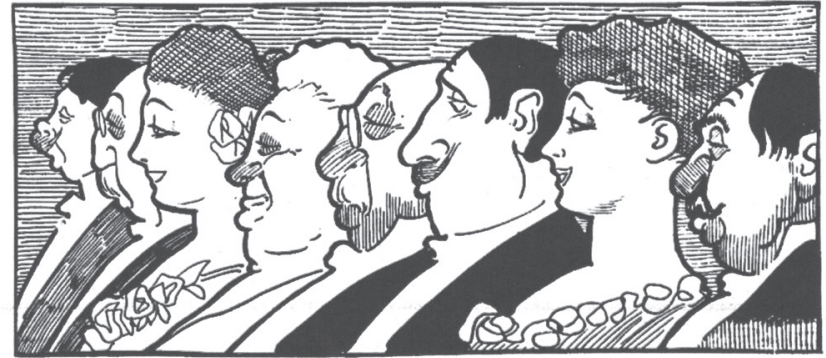

Fita . . . dos espectadores.

Figs. 5 e 6: O cinema como lugar de ver e ser visto. Careta, 14 de agosto de 1909; Careta, 19 de abril de 1913. Hemeroteca Digital Brasileira.

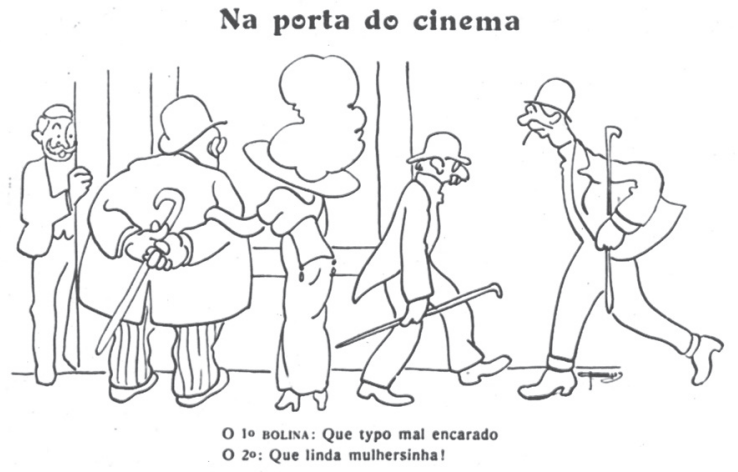

\footnotetext{
9 Termo que se refere aos homens que acossavam as mulheres nos espaços públicos.
}

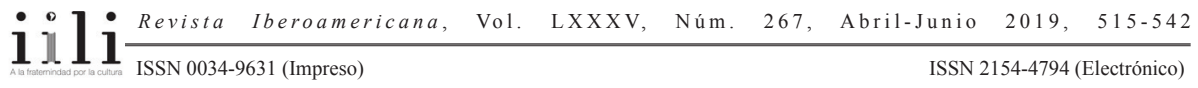


de avenidas ampliadas e eletrificadas. Na década seguinte, um colunista de Fon-Fon comenta: "se [o cinema] não existisse, a nossa Avenida Rio Branco seria um cemitério à noite! Imagine você se o Odeon, o Avenida, o Pathé, o Parisiense, o Cine-Palais fechassem todos, o que seria da animação que aí reina quando a Light ${ }^{10}$ derrama os seus jorros de luz" ("O assunto em foco", 17 out. 1914). Associadas com a tecnologia moderna de luz artificial e a "animação" própria de uma grande metrópole, as salas de cinema cariocas teriam um papel-chave na projeção de um Brasil moderno e urbano. Isso é evidente num texto humorístico publicado na Fon-Fon, acompanhado por desenhos, que narra a visita de um socialista alemão ao Rio de Janeiro (Fig. 7). $\mathrm{O}$ narrador o acompanha num passeio que demonstra "os grandes melhoramentos da

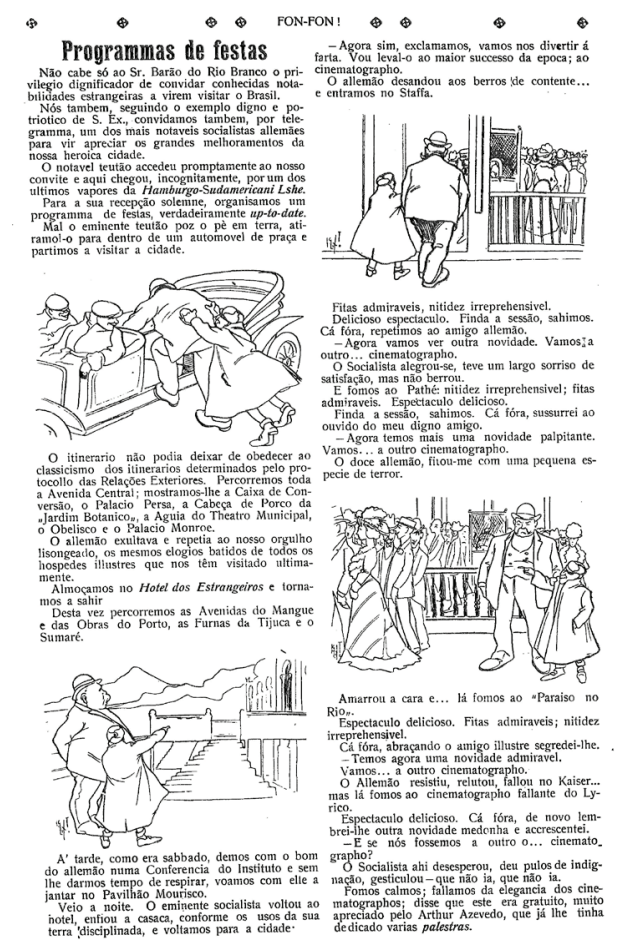

Fig. 7: As salas de cinema como atração turística e indício da modernidade. Fon-Fon, 19 de outubro de 1907.

Fundação Biblioteca Nacional, Brasil.

10 Uma referência à empresa elétrica canadense que fornecia luz ao Rio.

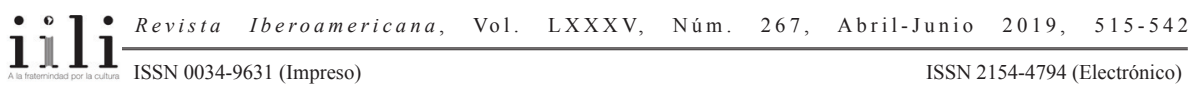


nossa heroica cidade", incluindo a emblemática Avenida Central (depois Avenida Rio Branco). Logo depois, eles fazem um passeio por tantas salas de cinema a ponto de o visitante começar a protestar. Uma multidão o obriga a assistir a uma última sessão, um comportamento que desmente a visão da cidade civilizada que o narrador procurava criar. A trajetória das personagens é narrada através de uma sequência de cenas escritas e desenhadas com qualidades protocinematográficas, que reúne diversos momentos e lugares no percurso das personagens através do espaço urbano.

Através da sua inserção na cidade remodelada, a sala de cinema torna-se um elemento essencial dos passeios públicos das classes privilegiadas. Os mencionados clichês de espectadores dentro e fora dos cinemas publicados nas revistas ilustradas documentam esses novos rituais das elites. As páginas de instantâneos chegam a manifestar uma alta complexidade visual, combinando imagens capturadas em vários momentos para dar uma impressão de movimentação nas ruas. Nessas imagens dominam as espectadoras femininas, sinalizando a presença da mulher no espaço público como uma novidade que a torna o objeto de um olhar implicitamente masculino (Melo Souza 45). Nesta imagem representativa de Fon-Fon de 1916, as espectadoras femininas dominam a multidão. Especialmente notável é a figura da jovem mulher de preto no centro da imagem, que serve como âncora visual da composição simétrica e como um possível ponto de identificação para quem lê a revista (Fig. 8). Tal como o leitor ou leitora, a jovem consome a cultura cinematográfica através de uma publicação impressa (possivelmente uma revista, mas mais provavelmente um programa ilustrado distribuído gratuitamente pelo proprietário do cinema).

A dificuldade de escapar dos olhares penetrantes dos transeuntes e os objetivos no espaço urbano são ironizados num verso curto publicado em 1909 na revista Fon-Fon: "Hoje, o infeliz carioca/Se do fotógrafo/Um acaso venturoso escapa/Surge na fita de um cinematógrafo" ("Raios X"). Além de evocar a "visibilidade das elites construída pelas revistas ilustradas", o verso se refere à prática de filmar as classes privilegiadas enquanto participavam de novas diversões (Melo Souza 152). Esses filmes curtos de corsos de carruagens na praia de Botafogo, batalhas de confete e jogos de futebol (ainda não uma diversão popular) exemplificam o gênero do "local film" cultivado pelo cinema dos primórdios, isto é, as vistas realizadas pelos exibidores para o consumo local. O seu apelo dependia da presença de cenários e figuras reconhecíveis pelo público, inclusive o mesmo espectador capturado numa ocasião anterior. De fato, alguns espectadores cariocas pediam que os operadores cinematográficos locais documentassem suas atividades, como era o caso de um grupo de remadores numa regata de 1908 . No mesmo ano, anunciou-se um filme que retratava os funerais dos almirantes Barroso e Saldanha, nos quais “conhecem-se pessoas, Oficiais do Exército e da Armada, senhoras etc.", de acordo com o jornalista Figueiredo Pimentel (apud Melo Souza 154). Esses filmes colocavam o público na posição de "both the subject and the object of the show" (Toulmin e Loiperdinger 16), possibilitando o autorreconhecimento do observador

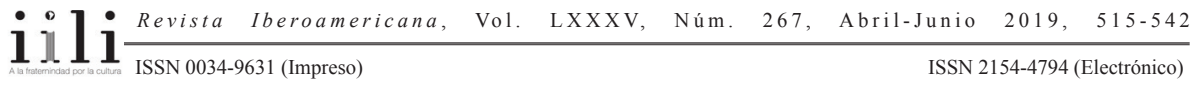




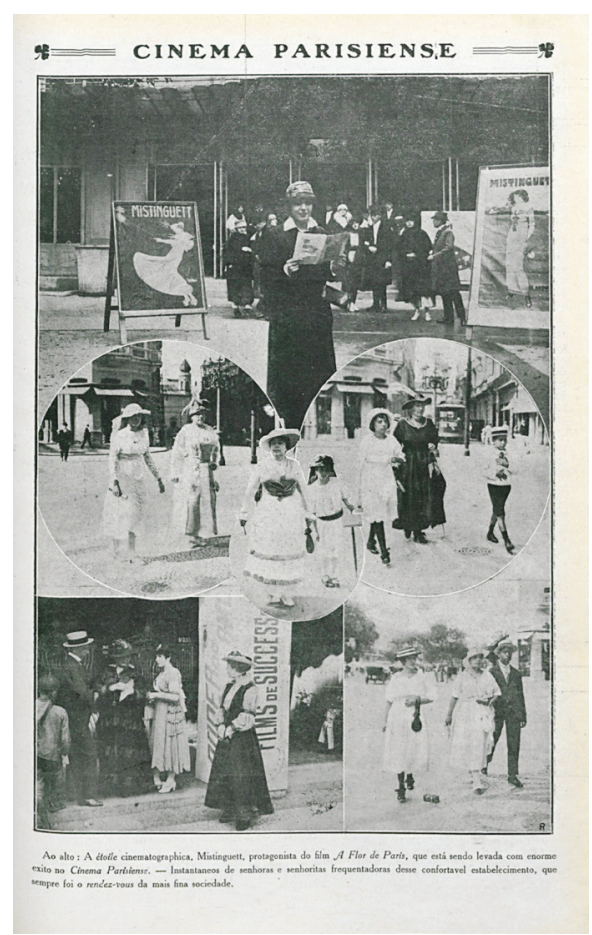

Fig. 8: Espectadoras femininas de cinema. FonFon, 18 de dezembro de 1916. Hemeroteca Digital Brasileira.

como parte do espetáculo da vida moderna. Não obstante as evidentes diferenças no regime de representação cinematográfica, os filmes dos "ciclos regionais" estenderiam essa dinâmica de reciprocidade entre ator e público.

Embora a confluência das reformas urbanas, do florescimento da imprensa ilustrada, da expansão do mercado de bens de consumo e da popularização de novas diversões e atividades de lazer fosse um fenômeno distintamente carioca, o papel do cinema como modelo para a estrutura da revista ilustrada não se limitava à então capital federal. Também nas cidades médias e pequenas, o novo meio torna-se ponto de referência para publicações que procuram retratar a comunidade leitora, frequentemente desde uma perspectiva sardônica. Os títulos de duas publicações efêmeras - O Cinema, de Caçapava, no Rio Grande do Sul (1912), e o Pathé Jornal, de Manaus (1913-1915) fazem paralelos entre o cinema e seus textos humorísticos e caricaturas, cujo propósito é essencialmente divulgar fofocas da comunidade local, "exhibi[ndo] fitas naturais apanhadas entre nós... no pano da publicidade" (Valli e Cunha 1). "Cinema" e "fita" aparecem como termos correntes para referir-se a fingimentos (desde casos de polícia

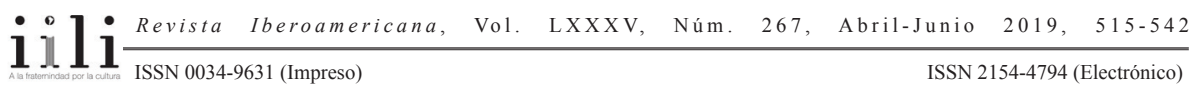


a charadas políticas) na imprensa de Porto Alegre em 1915 e em Salvador ao final da década (Steyer 139; Silva Fonseca 155-57). Esses exemplos indicam a recorrência de referências ao cinema como uma metáfora da mediação da vida cotidiana através da página impressa.

$\mathrm{Na}$ década seguinte, surgem revistas que interpelam o leitor como consumidor de cinema, as quais são órgãos dos cinemas locais ou estreitamente ligadas a eles. No Recife, o Teatro Moderno publica o Moderno-Jornal para seus espectadores gratuitamente e de forma diária entre 1918 e 1921. O Cine-Jornal de Campinas, uma publicação paga, estreia em janeiro de 1922. De extensão e tiragem reduzidas, essas publicações fundem aspectos da incipiente revista especializada de cinema com as funções do programa de mão distribuído nas funções. ${ }^{11} \mathrm{O}$ alcance local das publicações nos permite vislumbrar as dinâmicas da construção de uma cultura de consumo do cinema fora do contexto carioca e paulistano.

Nas duas publicações, o leitor/espectador é interpelado como colaborador e sujeito da revista. Em 1918, o Moderno-Jornal (possivelmente em imitação das revistas cariocas) promete tirar instantâneos dos seus espectadores. Porém, eles não chegam a ser publicados na revista, que aparentemente não tinha condições de incluir fotogravuras ("Instantâneos"). Ademais, a revistinha recifense solicita contribuições para a seção "O que eu notei no MODERNO [...] Exemplo: a beleza de Georges Wahl [sic], ${ }^{12}$ os lindos olhos negros da senhorinha F.[ulana], o artístico chapéu de mme. F., a elegância do jovem acadêmico F." (“O que eu notei”, 20 maio 1918, 2). É notável aqui a suposição de que a admiração pelo ator norte-americano coexistiria com a observação dos espectadores vizinhos. O olhar desejante do público poderia dirigir-se para um objeto próximo ou distante; ao ser traduzidas à página impressa, suas observações exibiriam e reproduziriam um conjunto de práticas sociais entendidas como modernas.

De maneira semelhante, nas suas páginas de Cine-Jornal, as imagens e a vida privada dos leitores e espectadores (mais precisamente, as do sexo feminino) apareceriam ao lado de informações e retratos das estrelas. Além de publicar fotos e fofocas sobre os artistas norte-americanos, a publicação campineira inclui em cada número um inquérito pessoal feito a uma senhorinha da sociedade local. Uma delas dá uma resposta sugestiva à pergunta "O que desejaria ser": "Uma estrela de cinema, para ser admirada por todos" ("Inquérito íntimo", 5 fev. 1922, 2). Em vez do familiar concurso de popularidade de artistas de cinema, o Cine-Jornal organiza uma votação para identificar "Qual a moça mais chique que frequenta as [funções] vesperais do Rink", um cinema local cuja ganhadora teria seu retrato publicado na primeira página

${ }^{11}$ Cine-Jornal possuía uma tiragem de cinco mil e depois três mil. (Cine-Jornal, 22 de janeiro de 1922 e 12 de fevereiro de 1922). A tiragem do Moderno-Jornal era de dois mil. (Moderno-Jornal, 24 de maio de 1918).

12 Provavelmente o ator George Walsh do estúdio Fox.

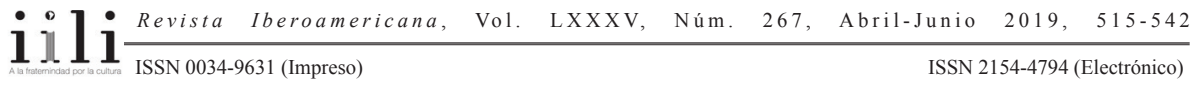


da revista ("Qual a moça" 2). Apesar da inclusão de elementos de interesse inteiramente local, Cine-Jornal afirma ser um concorrente sério para as publicações cariocas. A revista alega divulgar novidades de Hollywood que são "simultaneamente ou às vezes mesmo muito depois insertas em importantes revistas como 'Para Todos...', 'Scena Muda', etc.", procurando associar-se ao incipiente universo das revistas especializadas em cinema e suas conotações de atualidade ("Cine Jornal", 12 fev. 1922, 2). Cabe assinalar que até o surgimento de $A$ Tela em Porto Alegre, em 1928, nenhuma revista de cinema editada fora da então capital federal alcançaria imitar com sucesso o padrão das revistas cariocas. Significativamente, ao anunciar o lançamento de A Revista, em 1925, um grupo de jovens modernistas mineiros (incluindo Carlos Drummond de Andrade) declara, com ironia: "Supõe-se que ainda não estamos suficientemente aparelhados para manter uma revista de cultura, ou mesmo um simples semanário de bonecos cinematográficos" ("Para os céticos", jul. 1925, 11), como se uma revista de cinema fosse o requisito mínimo para uma imprensa local bem desenvolvida.

Por sua vez, as publicações cariocas miravam nos modelos importados. Em 1919, Para Todos... notou a presença numa livraria local de "novidades recebidas pelos últimos vapores sobre [o] assunto cinematográfico; são os lindos magazines Pictureplay, Photoplay, Motion Pictures News [sic], International Cinema, Cine-Mundial, Motion Pictures [sic] Magazine e Imparcial-Film" ("Revistas cinematográficas", 15 nov. 1919). Com a exceção desta última, publicada na Argentina, todas as demais procedem dos Estados Unidos. Esse panorama de publicações conserva elementos de etapas anteriores da imprensa especializada de cinema -material dirigido a exibidores (Motion Picture News, International Cinema, Cine-Mundial) ${ }^{13}$ e resumos ilustrados dos filmes em tom literário (Motion Picture Magazine tinha começado a ser publicada com o título Motion Picture Story Magazine) -, além de publicações que exemplificam o perfil mais familiar da revista de fã (Photoplay e Picture-Play).

Nesse momento, surgem no Rio publicações de vida curta como Palcos e Telas (1918-1919) e Cine-Revista (1919-1920) (Perez 312). A primeira tem características bastante particulares: mistura os anúncios e resenhas de filmes e os concursos de popularidade com textos mais imaginativos, que fazem dos artistas norte-americanos um ponto de partida para ficções originais. Por contraste, A Scena Muda (1921-1955) dedica-se principalmente aos resumos de filmes a serem estreados, com um número reduzido de artigos sobre estrelas ou assuntos cinematográficos em geral. Em muitos casos, eles eram assinados pelas estrelas, constituindo uma aproximação do artista de Hollywood com o leitor brasileiro sem solicitar a participação ativa deste. Ainda que vários resumos de produções nacionais fossem publicados em A Scena Muda, é

13 Os dois últimos eram publicações multilíngues (inglês, francês, espanhol, português e italiano no primeiro caso) impressas em Nova Iorque para um público internacional.

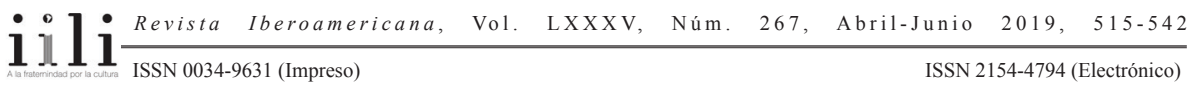


nas revistas Selecta, Para Todos... e Cinearte que se abre um amplo espaço para os debates em torno da produção, da exibição e do estrelato, forjando intercâmbios entre jornalistas cariocas, cineastas e leitores fora do Rio e de São Paulo que ressaltam as suas diversas visões da cultura cinematográfica moderna.

Olhares cariocas e visões regionais da modernidade em SElEcta, Para Todos... E CinEarte

Surgida em 1915, Selecta era uma publicação da Empresa Fon-Fon que inicialmente abrangia um conteúdo variado: crônicas, artigos de interesse geral, material literário e reportagens fotográficas da vida social das elites, incluindo instantâneos tomados na porta do Cinema Odeon. Em 1923, Selecta tinha iniciado a sua transformação "de simples revista de fatos e mundanismo que era... em um semanário cinematográfico" (“Cinematográficas", 3 jan. 1925). Em abril de 1924, a revista inicia a publicação da coluna "O Cinema no Brasil", em coordenação com Ademar Gonzaga em Para Todos... (Autran 55). Nessa última revista, a cobertura de assuntos cinematográficos tinha crescido de maneira mais gradual, embora, desde o seu primeiro número (de dezembro de 1918), uma estrela de Hollywood aparecesse em cada capa da revista. Quando a cobertura de cinema ameaça dominar a revista, nasce Cinearte, iniciativa de Gonzaga e Mário Behring lançada em março de 1926(Salles Gomes 295). A publicação é composta de resumos ilustrados de filmes a serem exibidos no Rio e em São Paulo, resenhas das estreias recentes, editoriais sobre a exibição, censura e regulamento de cinemas, artigos sobre estrelas e modas de Hollywood e a coluna "Filmagem Brasileira" (depois "Cinema Nacional"). Convidado por Gonzaga, Lima toma conta da coluna em fevereiro de 1927, permanecendo até 1930, quando corta a sua relação profissional com o outro jornalista (Araújo 236). Naquele momento, Cinearte tinha atingido uma tiragem de 60 mil exemplares (Campelo 68).

Atuando como "o natural intermediário entre os mercados consumidores brasileiros e o produtor norte-americano", nas palavras de Cinearte, as três revistas defendem a construção de cine-palácios de grande capacidade, luxo e conforto ("Crônica", 7 jun. 1927, 3). Essa ambição seria concretizada na Cinelândia, o complexo de cinemas construído no centro do Rio de Janeiro pelo empresário Francisco Serrador na primeira metade dos anos 1920. Os jornalistas tomam crédito dessa iniciativa de Serrador: "É uma vitória do Para Todos... força é confessá-lo, a construção d'essas novas casas [de espetáculos]. A nossa campanha contra os pequenos estabelecimentos da Avenida Rio Branco" - os mesmos que tinham sido elogiados por Fon-Fon em 1914 - "data dos primeiros números d'esta revista" (“Os nossos cinemas", 18 ago. 1923) De maneira semelhante, as revistas de cinema defendem os procedimentos de exibição reinantes nos Estados Unidos e o valor dos filmes mais recentes, sobretudo as "superproduções" de estúdios como Fox, Paramount e Metro.

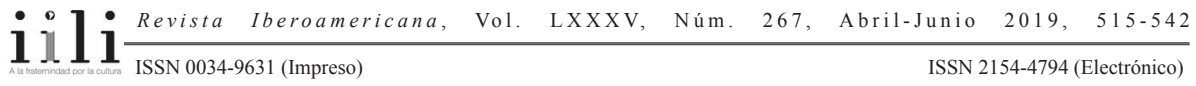


Embora as suas polêmicas e recomendações refiram-se quase exclusivamente ao Rio e a São Paulo, apesar do amplo público leitor fora dessas cidades, as revistas dedicam certo espaço às imagens e descrições da cultura de exibição em outras cidades precedentes dos seus leitores, com o intuito explícito de melhorar a cultura de exibição. Afinal de contas, o "progresso de um país mede-se pelo número dos seus cinemas" ("Cinemas e cinematografistas", 5 maio 1926, 2). Entre 1926 e 1929, Cinearte publica na seção "Cinemas e cinematografistas" fotos de fachadas de cinemas em Curitiba e Pelotas, entre outras, além de várias pequenas cidades do interior dos estados do Rio, São Paulo, Minas Gerais e Bahia, dando visibilidade aos espaços e práticas de cinema fora do Rio e de São Paulo. Nestas imagens de 1926 que retratam um novo cinema em Belém do Pará, por exemplo, estão claras as associações entre o espaço do cinema, a eletrificação e a presença das diversões "modernas" construídas pelas revistas ilustradas cariocas na década anterior. Vê-se uma fachada iluminada, uma sala de projeção cheia de espectadores e uma sala de espera, cenário privilegiado dos encontros sociais, ainda que seja modesta e meio vazia (Fig. 9).

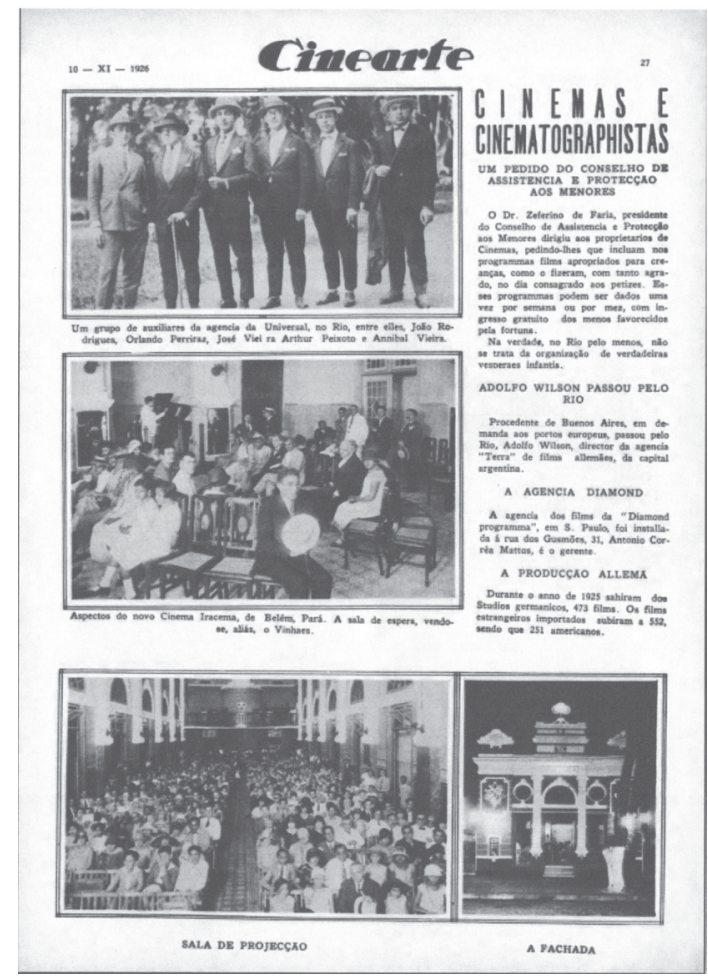

Fig. 9: Cinearte, 10 de novembro de 1926. Hemeroteca Digital Brasileira.

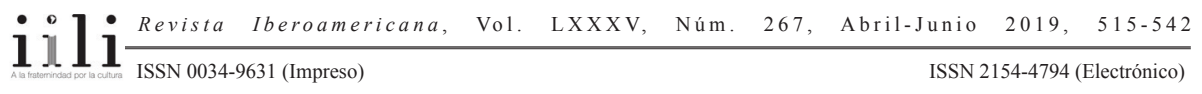


Em geral, porém, a visão da exibição fora das grandes cidades nas revistas de cinema cariocas limita-se a uma evocação da "linha", o circuito de cinemas de bairro e do interior onde se passavam os filmes depois de estrearem nas salas principais das duas cidades. Vale a pena citar longamente uma das descrições bastante sugestivas:

O importador adquire em geral para o Brasil, conforme a importância do filme, duas ou três cópias.

São essas cópias que passeiam o país de sul a norte, de Estado em Estado, passando de cidade para cidade, de cinema para cinema, de aparelho para aparelho, perdendo aqui alguns centímetros, mais além alguns metros e acabam sendo exibidas nos pontos extremos, meras sombras do que foram, riscadas, cheias de remendos com as perfurações dilaceradas, as legendas incompletas, incompreensíveis e volvendo enfim ao ponto de partida completamente inutilizadas para qualquer mister [....]

Essas linhas dependem das comunicações ferroviárias nos Estados centrais, sendo exibidas à noite e logo na madrugada seguinte embarcadas para outra cidade próxima, nessa peregrinação interminável. ("Linhas atravessadas", 20 out. 1923, 24)

Em vez de uma simultaneidade de estreias de um filme em múltiplas cidades, de acordo com o modelo de distribuição dos Estados Unidos, a linha constitui uma sucessão "interminável", acompanhada pela deterioração física da fita. Nas discussões da "linha", a extensão geográfica do país torna-se causa do atraso, e os preços baixos dos ingressos (que supostamente não justificavam o envio de cópias adicionais ao país) é obstáculo para o desenvolvimento de uma cultura de exibição desejável. Ainda que as revistas solicitem o empenho dos espectadores em melhorar essa situação através de queixas aos exibidores, a implicação era que, nos lugares mais afastados das grandes cidades, só era possível acompanhar a atualidade cinematográfica através da mediação da página impressa. A função pretendida da revista como veículo de consumo indireto da cultura cinematográfica é evidente nos resumos ilustrados dos filmes a serem estreados, incluindo os brasileiros, que não encontravam outros meios de difusão nacional. ${ }^{14}$

É possível reconstruir as condições locais de exibição nas colunas onde as revistas de cinema fornecem informações e novidades cinematográficas a leitores individuais, facilitando uma sensação de participação na cultura cinematográfica através das indagações do fã. Para Todos... inclui uma seção intitulada “Questionário”, de grande alcance geográfico; uma coluna de 1919, por exemplo, inclui cartas precedentes de Porto Alegre, Manaus e Natal, além de várias cidades dos estados do Rio, São Paulo e Minas Gerais (“Questionário”, n. p.). A seção “A página dos nossos leitores”, surgida

14 Por exemplo, Paulo e Virgínia (1924) e Vale dos martírios (1927), filmados na cidade pequena de Pouso Alegre, em Minas Gerais, por Almeida Fleming, Sofrer para gozar (dir. E.C. Kerrigan, Campinas, 1925), Tesouro perdido (dir. Humberto Mauro) e Senhorita agora mesmo (dir. Pedro Comello), realizados em Cataguases (MG) em 1927; Mocidade louca (dir. Felipe Ricci) e A filha do advogado (dir. Jota Soares).

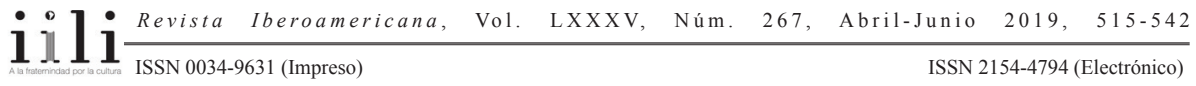


posteriormente, publica os comentários dos leitores sobre a exibição de filmes nas suas cidades, sobre suas estrelas preferidas e até sobre estética do cinema. Cinearte, e em menor medida Selecta, também solicitavam esse tipo de comunicação.

Mesmo anteriormente à aparição de colunas dedicadas à produção brasileira, pode-se perceber um diálogo (desigual) entre os jornalistas cariocas e os leitores fora do Rio. O primeiro assume um papel pedagógico de transmissor de conhecimentos da atualidade cinematográfica, enquanto o segundo é interpelado como colaborador na construção da modernidade brasileira. Em 1923, "Cyclone Smith"15 (pseudônimo do recifense Mário Mendonça [Araújo 236]), escreve:

A cinematografia nacional é um problema que até hoje permanece sem solução. Apesar de não residir no Rio da Janeiro, principal centro cinematográfico do país, julgo poder dizer algumas palavras acerca deste problema, orientado somente pelo o [sic] tenho lido no Para todos... e nos jornais e revistas cariocas. (“A página”, 17 mar. 1923, 9)

O que interessa aqui é menos a avaliação da situação feita por Mendonça - ele conclui que a falta de grandes capitais para inversão na produção condena os esforços ao fracasso - do que à referência a sua "orientação" às mãos da imprensa carioca e à sua vontade de enfrentar o assunto desde sua posição fora do "centro cinematográfico do país”. De fato, Mendonça subsidiará Pedro Lima com novidades sobre a atividade cinematográfica em Pernambuco ao longo da década de 1920, tal como outros leitores e cineastas.

Apresentando o fomento ao cinema brasileiro como projeto coletivo, ao iniciar a coluna "O cinema no Brasil”" Selecta coloca as suas "páginas à disposição dos interessados e dos leitores, para que sugiram e colaborem" ("Cinematográficas”, 26 abr. 1924). O editor parece surpreender-se com as respostas a essa chamada, escrevendo algumas semanas mais tarde sobre as "revelações" de iniciativas de produção cinematográfica em São Paulo e Minas Gerais ("Cinematográficas", 7 jun. 1924). Após vários anos de comunicações, conselhos e queixas dirigidos aos cineastas regionais, Lima e Gonzaga começam a recomendar a vinda dos cineastas ao Rio para que pudessem adquirir conhecimentos técnicos e para que seus filmes fossem avaliados pela crítica e os públicos - um passo essencial para o progresso do cinema brasileiro, de acordo com eles.

Mesmo quando não era possível fazê-lo pessoalmente, Gonzaga e Lima procuravam guiá-los de acordo com os seus valores morais e estéticos, na medida possível, à distância. Eles promovem o uso de interiores e vestuários luxuosos e a adesão à "lei dos tipos" (isto é, o princípio de que a aparência física do ator tinha que ser o princípio da distribuição dos papéis), de acordo como os critérios vigentes em Hollywood. Destaca-se entre seus princípios a rejeição veemente ao filme natural (documentário), concebido como

${ }_{15}$ Um personagem interpretado pelo ator norte-americano Eddie Polo numa série de filmes de aventuras.

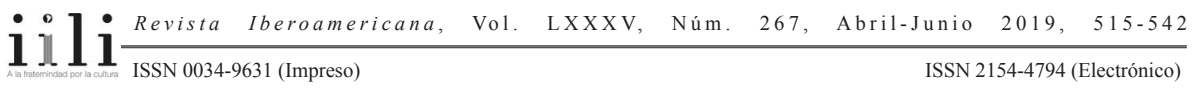


um veículo de exploração financeira (já que normalmente se tratavam de filmes de propaganda paga). Mais preocupantemente, o "filme natural" poderia mostrar regiões sem infraestrutura moderna ou indivíduos mestiços ou afrodescendentes que, de acordo com a ideologia racista da época, desprestigiariam o Brasil em outros países. "O imperativo da higiene, refletido nos constantes apelos à operação matriz de saneamento (do meio brasileiro, da imagem nossa no exterior, das salas de exibição), seria indispensável na realização de um cinema-vitrine, sedutor, publicitário" (Xavier 181).

O imperativo da publicidade é onipresente na campanha em prol do cinema brasileiro. Afirmando a sua importância para o sucesso da iniciativa, os jornalistas queixam-se continuamente do silêncio dos produtores e da quantidade e qualidade insuficiente das fotos recebidas. Como observa Luciana Corrêa deAraújo, há um evidente "descompasso entre as exigências dos dois críticos e as condições concretas de atuação das produtoras. Eles cobram procedimentos profissionais e esperam estabilidade de um meio marcado pela instabilidade" (Araújo 239). Apesar dos obstáculos práticos que paralisavam as atividades dos cineastas regionais, a cobertura do cinema brasileiro procura criar uma impressão de atividade contínua da produção cinematográfica no país, que constituiria um sinal de progresso em si (Araújo 239). Logra-se esse efeito através de justaposições de fotos fixas procedentes de várias cidades, o que cria uma sensação de simultaneidade das atividades de filmagem (Fig. 9). Neste exemplo da Cinearte de 1927, a página é preenchida com um arranjo denso de fotos pequenas, talvez uma consequência da baixa qualidade dos originais. Aparecem "estrelas" e filmes de diversas origens, incluindo produções pernambucanas (Herói do século XX), mineiras (Vale dos martírios) e gaúchas (Em defesa da irmã). Atrizes "verdadeiras" que já tinham aparecido na tela, como Guiomar Teixeira, protagonista do filme recifense $A$ filha do advogado, aparecem ao lado de aspirantes como Odalgiza B. Ormerod, ganhadora de um concurso local de popularidade patrocinado pelo Circuito Nacional de Exibidores, que examino detalhadamente mais adiante.

Central ao programa de publicidade das revistas é o fomento de um star system nacional através de artigos, entrevistas e fotografias glamurosas dos atores e atrizes que apareciam nos filmes brasileiros. Cinearte proporciona endereços das artistas para facilitar a correspondência dos fãs e noticia a grande quantidade de cartas recebidas (exagerada pelos jornalistas, é de se imaginar). Como assinala Paulo Emílio Salles Gomes, "num tempo em que os filmes das estrelas não eram vistos pelo público, a política do estrelismo se resumia em publicar fotografias que inspirassem cartas" (336). Gomes e outros historiadores concordam quanto à futilidade dessa política, julgando-a uma "imitação das revistas americanas sem bases reais" (Xavier 196). Em muitos casos, a imitação é evidente, como no caso dos arranjos simétricos de imagens da atriz brasileira Nita Ney e a norte-americana Sally Blane, com exceção do vestuário mais modesto de Ney (Fig. 10). Porém, Xavier não leva em consideração que as bases

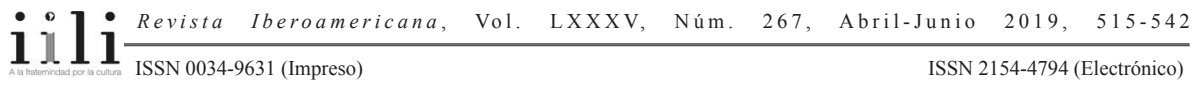


do star system sempre eram fantásticas, alimentadas por dialéticas de proximidade e distância inerentes à estrutura do estrelato e das revistas que o alimentam.

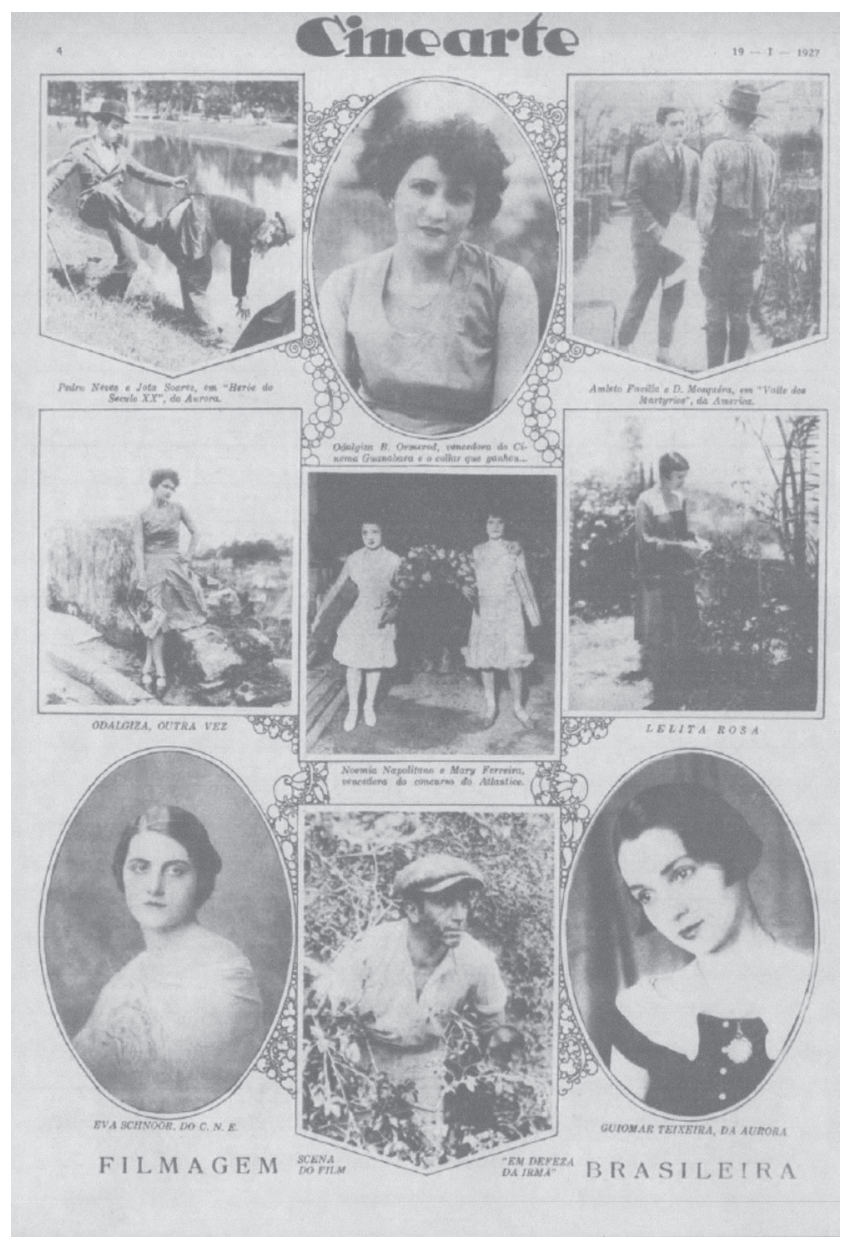

Fig. 10: "Filmagem brasileira", Cinearte, 19 de janeiro de 1927. Hemeroteca Digital Brasileira.

Para Todos..., Selecta e Cinearte constroem um estrelato de papel a partir dos intercâmbios entre atores, jornalistas e leitores, afirmando a existência de uma cultura cinematográfica nacional na ausência de uma indústria. Por exemplo, uma imagem de Almery Steves, que atuou em vários filmes pernambucanos, com uma cópia de Para Todos... evoca os métodos de promoção mútua utilizados por revistas norte-americanas

\begin{tabular}{l}
-111 \\
\hline ISSN 0034-9631 (Impreso)
\end{tabular} 
como Photoplay, que popularizavam os artistas e, ao publicar imagens deles lendo a revista, aproveitou-se dessa popularidade para fazer autopublicidade. A ironia aqui é que a circulação da revista era sem dúvida muito maior do que o número de fãs da atriz (Fig. 11). Outro elemento essencial à criação de um star system brasileiro era a entrevista. De acordo com as convenções desse gênero, os jornalistas inevitavelmente expressam trepidação e entusiasmo ao enfrentar as artistas brasileiras. $\mathrm{O}$ jornalista Paulo Wanderley escreve acerca do seu encontro com Eva Nil: "Eu estava falando a uma estrela de Cinema, e estrela de Cinema de minha pátria. A minha emoção foi enorme, a emoção de um 'fan' antigo de mais de dez anos!" (Wanderley 7). Através desta encenação do encontro entre o jornalista e a "estrela" brasileira, Cinearte afirma que os artistas e os filmes nacionais são dignos dos excessos afetivos provocados pelos astros de Hollywood. Em outro texto sobre Nil, um detalhe que ressalta o caráter local da filmagem é apresentado como evidência de um estrelato legítimo. Cinearte anuncia que ela tinha feito um "personal appearance" [em inglês no original] na estreia, em Cataguases, do seu filme de aventuras Senhorita agora mesmo, "a primeira vez que isto acontece no Brasil" ("Cinema brasileiro", 19 fev. 1928, 6). Ainda que a presença da atriz numa sala de cinema da cidade onde ela morava fosse uma ocorrência inteiramente banal, a revista associou o fato com uma prática de publicidade norte-americana. Normalmente o "personal appearance" estimularia a fascinação com a estrela ao diminuir a distância entre ela e o espectador. Apesar da proximidade já excessiva da estrela, Cinearte evoca os protocolos do estrelato de Hollywood para solicitar a fascinação do leitor.
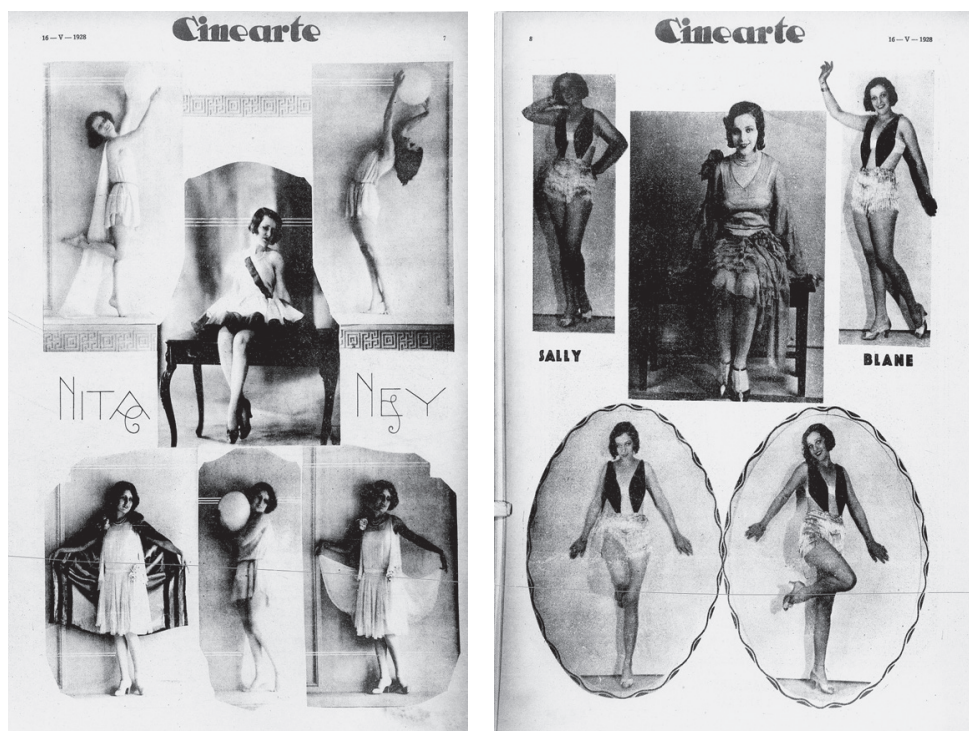

Fig. 11: A brasileira Nita Ney e a americana Sally Blane em Cinearte, 16 de maio de 1928. Hemeroteca Digital Brasileira.

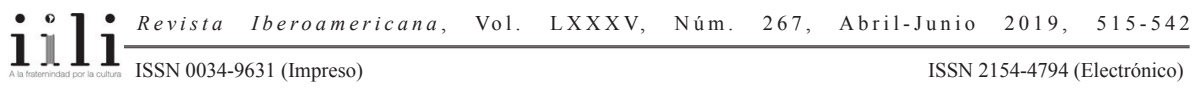




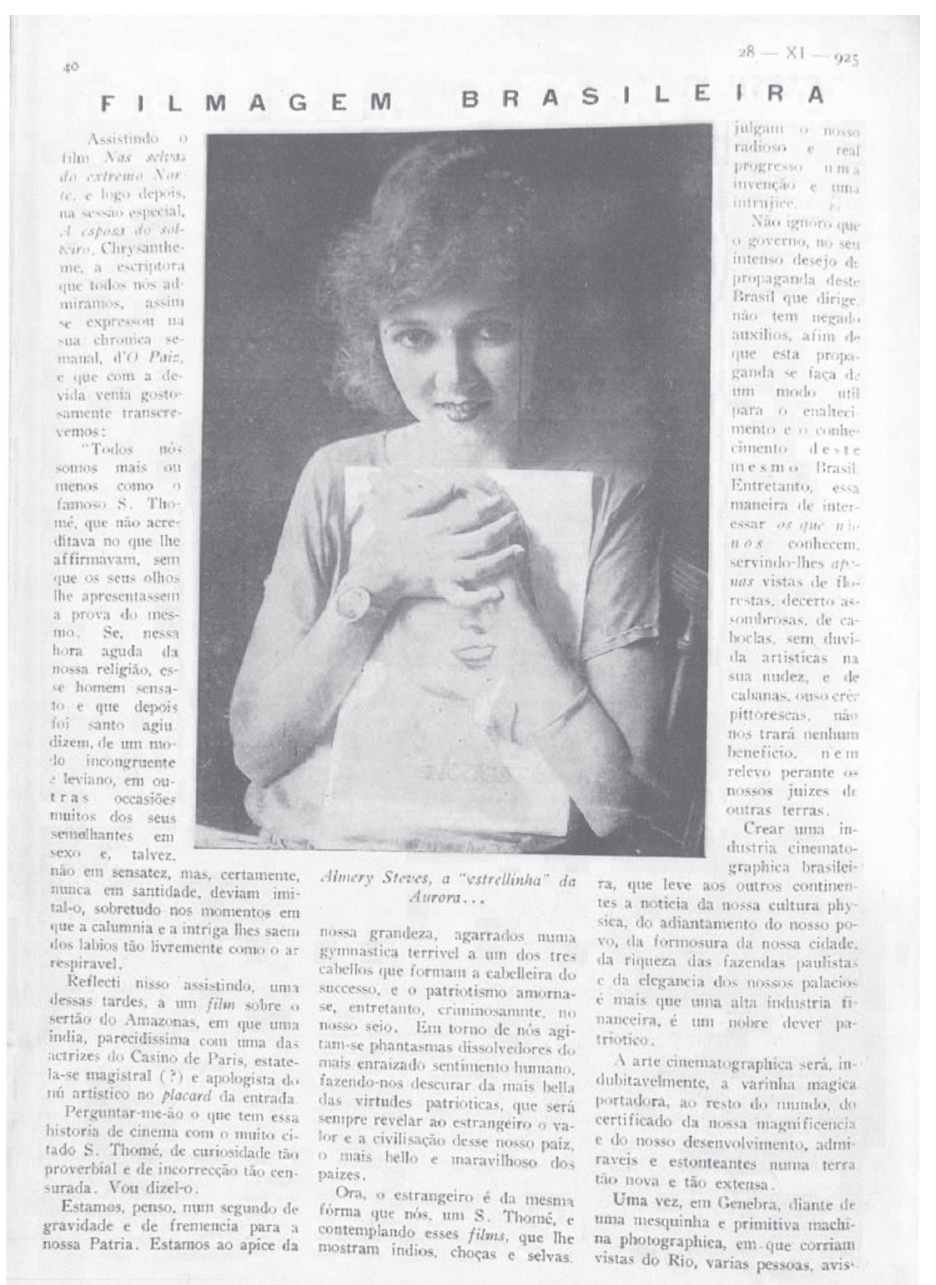

Fig. 12: A atriz Almery Steves como leitora. Para Todos... 28 de novembro de 1925. Acervo Jota Carlos em Revista.

Tal como as revistas de fã norte-americanas, Cinearte oferece aos leitores a oportunidade de eliminar por completo a distância (relativamente pequena) entre leitor e artista, aumentando o seu prestígio no processo. Em junho de 1926, a revista oferece seus serviços como agente de casting, perguntando aos leitores "Quem quer posar nos filmes brasileiros?" e fornecendo uma ficha que, após ser preenchida e remetida pelo leitor, seria guardada no arquivo da revista para a consulta pelos produtores de filmes ("Quem quer posar", 16 jun. 1926, 5). A revista anunciou a seleção da

11
11 
protagonista de Braza dormida através deste método, embora no final ela não tenha chegado a aparecer no filme. ${ }^{16}$ Ao lado da sua cobertura do "Concurso fotogênico" da Fox, cujos dois ganhadores teriam o direito de viajar para Hollywood e atuar nos filmes da empresa, ${ }^{17}$ Cinearte dá notícias de outro concurso patrocinado pelo Circuito Nacional de Exibidores, uma organização que procurava promover a distribuição de filmes brasileiros. Numa iniciativa que se assemelha ao concurso de Cine-Jornal, as concorrentes nesse concurso de beleza seriam selecionadas pelos frequentadores de cada cinema membro da associação. À ganhadora, selecionada entre as "rainhas" dos cinemas locais, seria dada a oportunidade de interpretar um papel no primeiro filme produzido pela organização ("Filmagem brasileira", 18 ago. 1926, 4). Talvez mais importante, as jovens veriam seus retratos publicados nas páginas da revista ao lado das estrelas norte-americanas e brasileiras.

No contexto do estrelato precário das artistas brasileiros, exagera-se a permeabilidade nas categorias de espectador e protagonista, já elemento fundamental da cultura de fã. Em 1924, a atriz campineira Cacilda Alencar declara para Selecta: "Certo era, que sempre fui grande admiradora da arte muda, fervorosamente, e a considerava como um pináculo inaccessível, sem nunca supor no entanto, ser um dia artista de cinema! Bem devem imaginar portanto a minha impressão, quando me vi assim de um momento para outro, posando diante de uma objetiva cinematográfica!" ("Como ingressei”, 8 nov. 1924). ${ }^{18}$ Nesse relato, a experiência de se tornar o objeto do aparelho é transformativa em si. A descrição de Alencar das motivações dos cineastas campineiros indica uma interseção de ambições individuais, locais e nacionais: "Posamos sim, naqueles filmes, para satisfazer um desejo e por experiência; desejávamos colaborar também com nossos esforços, para mostrar ao mundo, que se o Brasil quiser, também pode produzir a arte" ("Como ingressei", 8 nov. 1924). Além do discurso familiar de progresso e orgulho nacional, ressalta-se aqui o desejo de fazer filmes como "experiência" (da modernidade), que não necessariamente dependia do filme ser visto ao nível nacional. Os filmes regionais também provocam desejos de participação nos espectadores mais próximos. Falando da exibição de um filme de aventuras recifense, um leitor de Gravatá, em Pernambuco, comenta: “A plateia daqui recebeu Jurando vingar debaixo de uma forte salva de palmas. Achei justo e entusiasmei-me, pois, sempre sonhei com

16 De acordo com Lima ("Cinema brasileiro", Cinearte, 8 de fevereiro de 1928, 7), trata-se de uma jovem com o nome artístico Thamar Moema, que por razões de saúde não pôde continuar na rodagem (Lima, “Cinema brasileiro," Cinearte, 9 de maio de 1928, 6).

17 Nenhum dos ganhadores, Olympio Guilherme e Lia Torá, alcançaria grande sucesso em Hollywood após desempenhar papéis menores em um punhado de filmes. Para uma discussão da carreira de Guilherme como escritor, cineasta e crítico de Hollywood, ver Borge 158-76.

18 Cabe ressaltar que Alencar também declara que "nunca pisara sequer um palco [....] nem me exibia jamais de forma alguma", enfatizando sua falta de experiência como atriz, para evitar as acusações de imoralidade experimentadas pelas atrizes brasileiras. Ver Baptista Bicalho 21-33.

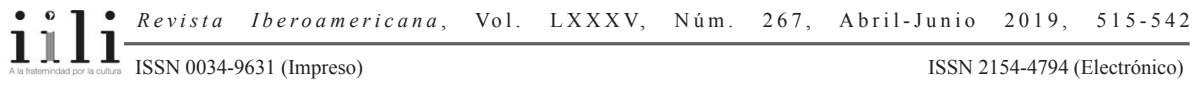


o cinema brasileiro. É pena não poder fazer parte dele” (“A página”, 14 nov. 1925, 7). Dada a proximidade geográfica das atividades de produção cinematográfica no Recife, o sonho de participar do cinema brasileiro tornou-se (quase) alcançável.

Essa experiência de participação possibilitada pela produção regional foi amargamente criticada pelas revistas de cinema. Em 1928, um jornalista de Selecta comenta: "Essas tentativas sem objetivo nacional, essas películas feitas quase para os amigos ver, não são nada para a grandeza da Pátria Brasileira, que espera uma obra de maior alcance e de resultados artísticos mais fortes" ("O ano que vai findar", 7 nov. 1928). Insistindo na integração dos filmes nacionais nos circuitos estabelecidos para os filmes importados, os jornalistas rejeitam as estratégias de exibição adotadas pelos produtores regionais - alugar cinemas locais para as estreias, acompanhar os filmes pessoalmente numa turnê por salas na região, ou aproveitar as estradas de ferro como uma rede de distribuição regional. ${ }^{19}$ Referindo-se ao filme Amor que redime (E.C. Kerrigan, Porto Alegre, 1928), Lima comenta o desinteresse da empresa produtora nos "mercados do Rio e S. Paulo, sem dúvida os dois mais importantes do país. Em geral, todo o filme para fazer linha, são lançados primeiramente neste dois mercados, daí se irradiando para todo Brasil" ("Cinema brasileiro", 18 jan. 1928, 38). Ainda que o sistema da "linha" não seja aceitável, Lima não é capaz de imaginar a viabilidade de uma rede de distribuição local, nem um cinema sem ambições nacionais. Para ele, esse cinema, o único de valor, tinha que passar à força pelo Rio de Janeiro e por São Paulo.

Os discursos de modernização nacional das revistas cariocas de cinema não admitem uma imagem da modernidade produzida e consumida ao nível local, que estende as dinâmicas de reconhecimento e participação que tinham caraterizado a cultura visual brasileira desde a virada do século XX. A presença dos filmes regionais nas páginas das revistas cariocas constitui uma intersecção de dois projetos de modernização às vezes incompatíveis: as ambições simultaneamente nacionalistas e cosmopolitas dos jornalistas do Rio, e os alvos dos cineastas regionais engajados na construção de um cinema brasileiro, mas com o olhar nos horizontes mais próximos. Os seus projetos se cruzam, no entanto, no desejo de ver o Brasil através da objetiva, um ato de mediação que constituiria uma prova de modernidade. Nas primeiras décadas do século XX no Brasil, esse modo de participação na modernidade era possível principalmente através da página impressa, um espaço contraditório onde a midiatização da vida cotidiana poderia florescer ao lado dos produtos de uma indústria cultural importada.

${ }^{19}$ Essa última estratégia foi utilizada no caso do filme campineiro João da Mata (1923), de acordo com Carlos Roberto de Souza, 54-60. Certo é que alguns produtores tinham ambições nacionais: em carta a Pedro Lima datada 5 de dezembro de 1924, o diretor recifense Gentil Roiz propõe trazer seu filme Retribuição "ao Sul, onde fará o seguinte Linha. Rio, S. Paulo, Rio Grande, Minas, e Bahia, regressando então ao Norte".

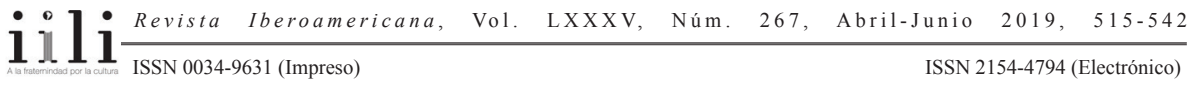




\section{OBRAS CITADAS}

“O ano que vai findar". Selecta. 7 nov. 1928: n.p.

"O assunto em foco". Fon-Fon. 17 out. 1914: n.p.

Araújo, Luciana Corrêa de. "O cinema silencioso pernambucano segundo as revistas cariocas”. Estudos SOCINE de Cinema IV. São Paulo: Nojosa Edições, 2005. 236-42.

Autran, Arthur. "Pedro Lima em Selecta". Cinemais 7/7 (1997): 53-65.

Azevedo, Neroaldo Pontes de. Modernismo e regionalismo: os anos 20 em Pernambuco. João Pessoa: Secretaria de Educação e Cultura da Paraíba, 1984.

Benjamin, Walter. Obras escolhidas. V. 1. São Paulo: Brasiliense, 1994.

Bicalho, Maria Fernanda Baptista. "The Art of Seduction: Representation of Women in Brazilian Silent Cinema". Luso-Brazilian Review 30/1 (1993): 21-33.

Bomeny, Helena. Guardiães da razão: modernistas mineiros. Rio de Janeiro: Editora UFRJ, 1994.

Borge, Jason. "Olympio Guilherme: Hollywood Actor, Auteur and Author". LusoBrazilian Review 44/1 (2007): 158-76.

Campelo, Taís Lucas. "Cinearte: o cinema brasileiro em revista (1926-1942)". Dissertação de mestrado. Universidade Federal Fluminense, 2005.

“Cine Jornal”. Cine-Jornal. 12 fev. 1922: 2.

"Cinemas e cinematografistas". Cinearte. 5 maio 1926: 2.

“Cinematográficas”. Selecta. 26 abr. 1924: n.p.

"Cinematográficas". Selecta. 7 jun. 1924: n.p.

“Cinematográficas". Selecta. 25 out. 1924: n.p.

“Cinematográficas". Selecta. 3 jan. 1925: n.p.

“Cinematográficas". Selecta. 20 mar. 1929: 3.

Conde, Maite. Consuming Visions: Cinema, Writing, and Modernity in Rio de Janeiro. Charlottesville: U of Virginia P, 2011.

"Crônica”. Cinearte. 1 jun. 1927: 3.

Cunha Filho, Paulo Carneiro da. A utopia provinciana: Recife, cinema, melancolia. Recife: Editora Universitária UFPE, 2010.

Eleutério, Maria de Lourdes. "Imprensa a serviço do progresso". História da Imprensa no Brasil. Ana Luíza Martins e Tania Regina de Luca (orgs.). São Paulo: Editora Contexto, 2008. 83-102.

"Filmagem brasileira". Cinearte. 18 ago. 1926: 4.

"O fulgor das nossas estrelas: uma entrevista com Polly de Vienna". Cinearte. 12 maio 1926: 5.

"Inquérito intimo". Cine-Jornal. 5 fev. 1922.

"Instantâneos". Moderno-Jornal. 9 jun. 1918: 3.

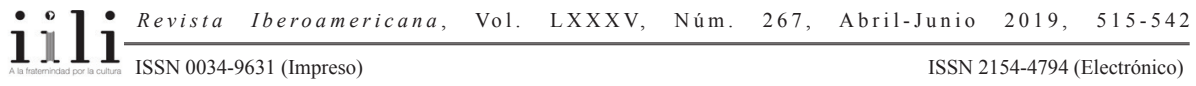


"Klaxon". Klaxon. 15 maio 1922: n.p.

Lima, Pedro. "Cinema brasileiro". Cinearte. 18 jan. 1928: 7.

"Cinema brasileiro". Cinearte. 8 fev. 1928: 7.

"Cinema brasileiro". Cinearte. 19 fev. 1928: 6.

"Cinema brasileiro". Cinearte. 9 maio 1928: 6.

"Como ingressei no cinema". Selecta. 8 nov.1924: n.p.

"Desenvolvimento da Filmagem Brasileira". Selecta.1 dez. 1926: n.p.

“Onde será a Los Angeles do Brasil?". Selecta. 19 jul. 1924: n.p.

"Linhas atravessadas". Para Todos... 20 out. 1923: n.p.

López, Ana M. "Early Cinema and Modernity in Latin America". Cinema Journal 40/1 (2000): 48-78.

Martín Barbero, Jesús. De los medios a las mediaciones: comunicación, cultura y hegemonía. México, D.F.: Ediciones G. Gili, 1987.

Melo Souza, José Inácio de. Imagens do passado: São Paulo e Rio de Janeiro nos primórdios do cinema. São Paulo: Editora Senac, 2004.

"O que eu notei no MODERNO". Moderno-Jornal. 20 maio 1918: 1-2.

"Os nossos cinemas". Para Todos... 18 ago. 1923: n.p.

Orgeron, Marsha. "'You are Invited to Participate': Interactive Fandom in the Age of the Movie Magazine". Journal of Film and Video 61/3 (2009): 3-23.

“A página dos nossos leitores”. Para Todos... 17 mar. 1923: 9.

“A página dos nossos leitores”. Para Todos... 14 nov. 1925: 7.

"Para os céticos". A Revista. Julho 1925: 11.

Perez, Eliane. "O cinema brasileiro em periódicos, 1896-1930". Anais da Biblioteca Nacional 122 (2002): 291-338.

"Qual a moça mais chique que frequenta as vesperais do Rink?". Cine-Jornal, 15 março 1922: 2.

“Quem quer posar nos filmes brasileiros?". Cinearte. 16 jun. 1926: 5.

"Questionário". Para Todos... 4 out. 1919: n.p.

"Raios X”. Fon-Fon. 27 jun. 1908: n.p.

"Revistas cinematográficas". Para Todos... 15 nov. 1919: n.p.

Rodrigues, Marly. O Brasil na década de 1920: os anos que mudaram tudo. São Paulo: Editora Ática, 1997.

Roiz, Gentil. "Carta para Pedro Leiva. Recife, 1924.07.23". Arquivo Pedro Lima, Cinemateca brasileria, APL-C/28.

Silva Fonseca, Raimundo Nonato da. 'Fazendo fita': cinematógrafos, cotidiano e imaginário em Salvador, 1897-1930. Salvador: Universidade Federal da Bahia, 2002.

Salles Gomes, Paulo Emílio. "O cinema brasileiro visto de Cinearte". Humberto Mauro, Cataguases, Cinearte. São Paulo: Editora Perspectiva, 1974. 295-354.

Souza, Carlos Roberto de. "Cinema em Campinas nos anos 20 ou uma Hollywood brasileira”. Dissertação de mestrado, Universidade de São Paulo, 1979. 54-60.

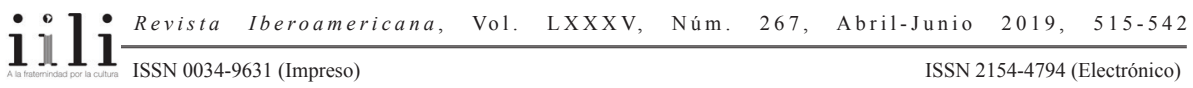


Steyer, Fábio Augusto. Cinema, imprensa e sociedade em Porto Alegre (1896-1930). Porto Alegre: EDIPUCRS, 2001.

Süssekind, Flora. Cinematógrafo de letras: literatura, técnica emodernização no Brasil. São Paulo: Companhia das Letras, 1987.

Toulmin, Vanessa e Martin Loiperdinger. "Is it You? Recognition, Representation and Response in Relation to the Local Film". Film History 17/1 (2005): 7-18.

Valli, Vincente e Jango Cunha. "A estreia". O Cinema, 12 maio 1912: 1.

Wanderley, Paulo. "Eva Nil”. Cinearte. 26 out. 1927: 7.

Xavier, Ismail. "O sonho da indústria: a criação de imagem em Cinearte". Sétima arte: um culto moderno. São Paulo: Editora Perspectiva, 1978. 167-197.

Palavras chave: cinema, imprensa ilustrada, modernização, regionalismo

Recibido: $\quad$ junho 2016

Aprobado: $\quad$ setembro 2018 